\title{
COMPARISON OF N-TERMINAL AMINO ACID SEQUENCE OF FISH ROE RHAMNOSE-BINDING LECTINS
}

\author{
Masahiro Hosono ${ }^{1}$, Kyoko Matsuda ${ }^{1}$, Hiroaki Kawauchi ${ }^{1, \dagger}$, Yoshio Takayanagi ${ }^{1}$, Hiromi \\ Shiokawa ${ }^{2}$, Reiko Mineki ${ }^{2}$, Kimie Murayama ${ }^{2}$ and Kazuo Nitta ${ }^{1,3}$ \\ ${ }^{1}$ Cancer Research Institute, Tohoku College of Pharmaceutical Sciences, Aobaku, Sendai 981, and ${ }^{2}$ Division of Biochemical \\ Analysis, Central Laboratory of Medical Sciences, Juntendo University, School of Medicine, Bunkyoku, Tokyo 113, Japan
}

\begin{abstract}
A 26-KDa rhamnose-binding lectin was purified from roe of shishamo smelt (Osmerus lanceolatus) by sequential chromatographies of DE23 anion exchange, D-galactoseSepharose and TSK gel CM-5PW. This lectin (OLL) agglutinated rabbit and human ABOtype erythrocytes and sarcoma 180 cells. The lectin-induced hemagglutination was inhibited by L-rhamnose. The amino acid composition of OLL was similar to that of Osmerus eperlanus mordax roe lectin-4 (OML-4). The N-terminal 34 amino acid sequence of OLL was VTTDIXEGQQATLNXGSSVINVVSANYGRTDRVT (X: not defined) and similar to that of OML-4. Therefore, OLL and OML-4 may be the same lectin existing in the different species of fish roe.
\end{abstract}

Lectins are carbohydrate-binding proteins which agglutinate erythrocytes and other cells (6). Clinical applications of lectins at the present time are multiple, including (i) classification of various blood groups or types $(4,20)$, (ii) detection of polyagglutination induced by T-antigen $(14,15)$, (iii) evaluation of the immunocompetence of patients including AIDS (23), (iv) detection of tumors by recognition of tumor markers (24), and (v) histochemical approach toward the clinical investigations (5). In recent years, an interest has been taken in the relation between lectins and cell adhesion molecules. There are a great number of reports on selectins $(1,2,9)$ which mediate adhesive interactions between circulating leukocytes and the vascular endothelium at a part of inflamed or injured venules with a carbohydrate-recognition mechanism.

Grillon et al. (7) reported that human granulocytes express rhamnose-binding lectin on their cell surface and their expression is modulated by mononuclear cells and granulocyte/macrophage colony-stimulating factor, but not by phorbol

${ }^{\dagger}$ Deceased

${ }^{3}$ To whom correspondence should be addressed myristate acetate. Rhamnose-binding lectins have been found mostly in fish roe (10). One of the biological roles of these lectins is thought to participate in defense mechanisms against pathogenic bacterium. Ozaki et al. (19) reported on a rhamnose-binding lectin from amago (Oncoryncus rhodrus) roe and its receptor on macrophages. They suggested that a lectin receptor was expressed on peritoneal macrophages of amago after inflammatory stimulation.

In this paper, we describe the purification and characterization of shishamo smelt (Osmerus lanceolatus) roe lectin (OLL), and compare the Nterminal amino acid sequence between OLL and other fish roe rhamnose-binding lectins.

\section{MATERIALS AND METHODS}

\section{Materials}

Shishamo smelt (Osmerus lanceolatus) and olive rainbow smelt (Osmerus eperlanus mordax) were obtained in Hokkaido Prefecture, and catfish (Silurus asotus) in Fukushima Prefecture. Sepharose 6B was purchased from Pharmacia-LKB, standard proteins used for molecular weight estimation by sodium dodecyl sulfate-polyacrylamide 


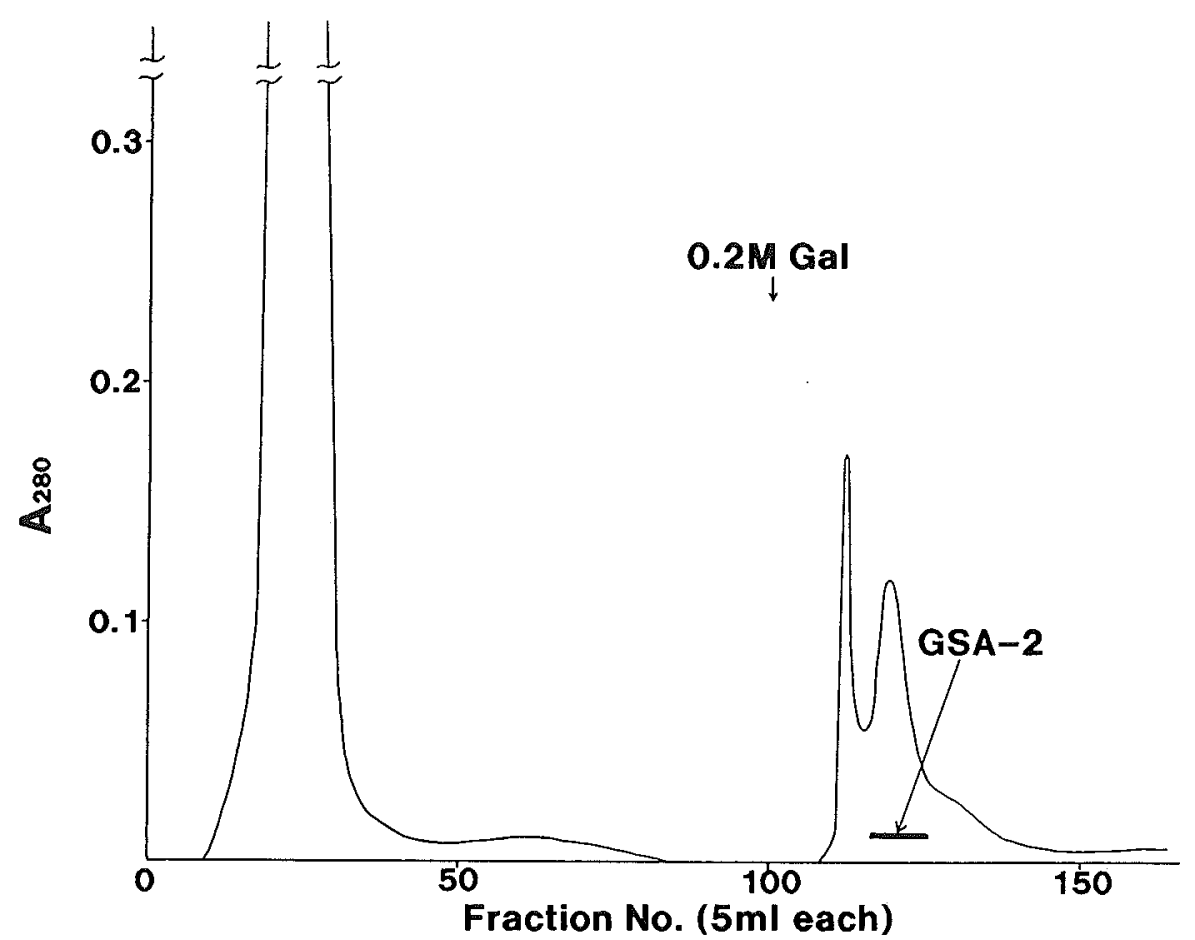

Fig. 1 Affinity chromatography of D10 derived from roe of 0 . lanceolatus on galactose-Sepharose. D10 $(500 \mathrm{mg})$ was applied to the column $(2.2 \times 20 \mathrm{~cm})$. The column was washed with $50 \mathrm{mM}$ acetate buffer $(\mathrm{pH} 5.5$ ) containing $0.15 \mathrm{M} \mathrm{NaCl}$. GSA-2 indicated with bar was eluted with the same buffer containing $0.2 \mathrm{M}$ galactose at a flow rate of $3 \mathrm{ml} / \mathrm{min}$ and fractions No. 116-125 were collected.

gel electrophoresis (SDS-PAGE) from Bio-Rad and DE23 anion exchange resin from Whatman. All other chemicals used were of the highest purity available.

\section{Purification of Fish Roe Rhamnose-Binding Lectins}

The main purification procedure of fish roe lectins was described previously (8). Briefly, Silurus asotus lectin (SAL) was purified by DE23 anion-exchange chromatography and D-galactose-Sepharose affinity chromatography. DE23 column was equilibrated with $10 \mathrm{mM}$ phosphate buffer (PB, pH 6.8) and eluted with a stepwise increase in the molarity (10, 100 and $200 \mathrm{mM}$ ) of PB. Galactose-Sepharose column was equilibrated with $50 \mathrm{mM}$ acetate buffer (pH 5.5) containing $0.15 \mathrm{M} \mathrm{NaCl}$ and SAL was eluted with the same buffer containing $0.2 \mathrm{M}$ Dgalactose. Four Osmerus eperlanus mordax lectins (OML-1 4) were purified by a combination of procedures described above and high performance liquid chromatography (HPLC) on a column of
TSK gel CM-5PW $(7.5 \times 75 \mathrm{~mm}$, Toso) (unpublished data). In case of purification of OLL, the affinity chromatography of the active fraction eluted with $10 \mathrm{mM}$ PB from DE23 column (D10), produced two adsorbed fractions (Fig. 1). The second fraction, GSA-2, was further purified by HPLC on a same column described above equilibrated with $10 \mathrm{mM} \mathrm{PB}(\mathrm{pH} 6.0)$ using a linear gradient of $\mathrm{NaCl}$ $(0-0.6 \mathrm{M})$ at a flow rate of $1.0 \mathrm{ml} / \mathrm{min}$, and then rechromatographed with $0.2-0.6 \mathrm{M} \mathrm{NaCl}$ gradient (Fig. 2). All the fractions obtained from each purification step described here were thoroughly dialyzed against distilled water and then lyophilized.

\section{Agglutination Assay and Inhibition Assay}

Hemagglutination assay and tumor cell agglutination assay were performed in $10 \mathrm{mM}$ PB containing $0.15 \mathrm{M} \mathrm{NaCl}$ as described previously $(17,18)$. One hemagglutination unit (HU) is defined as the minimum amount of protein $(\mu \mathrm{g})$ required for positive agglutination of a $2 \%$ rabbit erythrocyte suspension $(1 \mathrm{ml})$. The inhibitory activities of saccharides were 

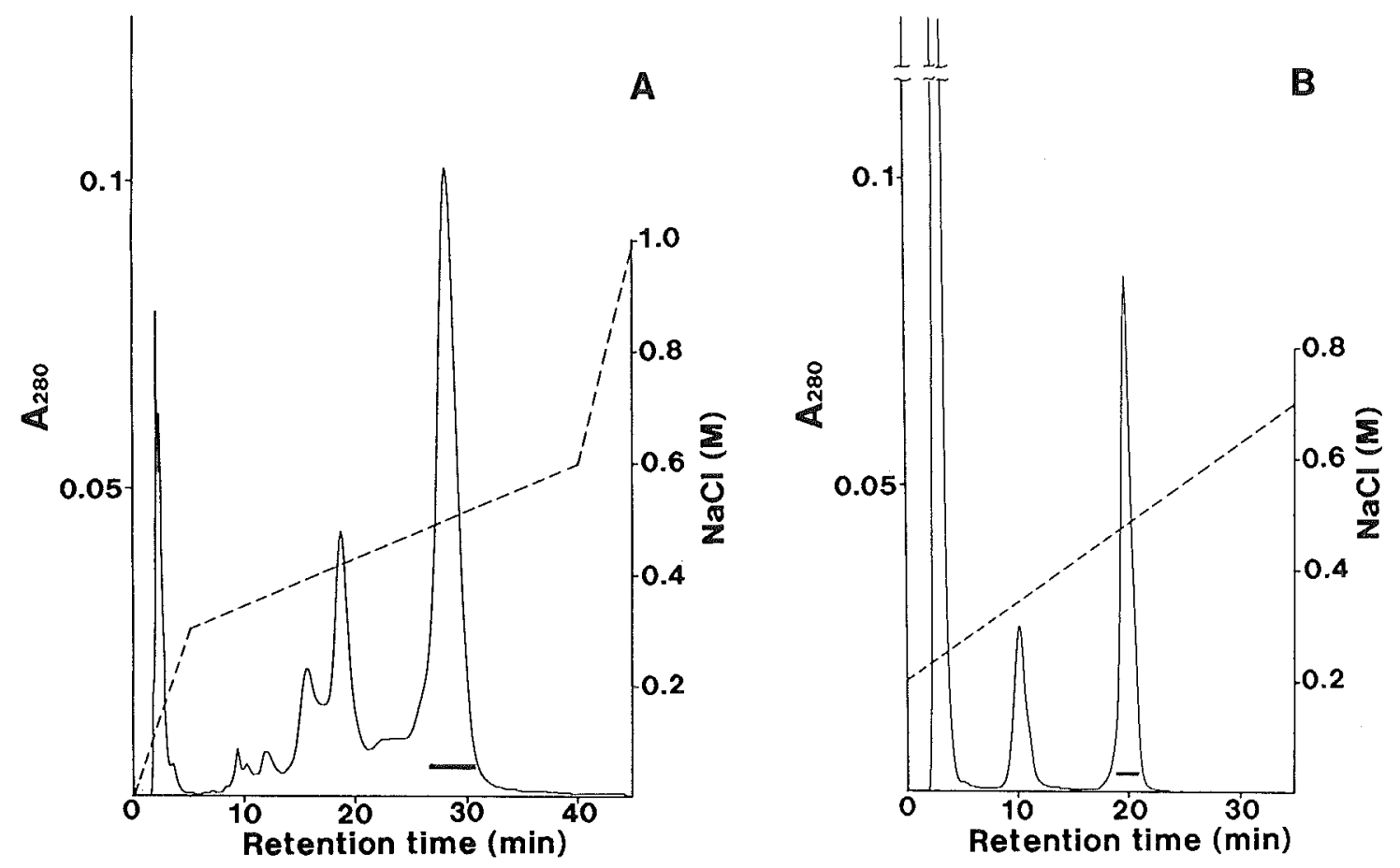

Fig. 2 HPLC pattern of GSA-2 on a column of TSK gel CM-5PW. (A) GSA-2 (500 mg) was applied to the column. The active fraction eluted with $0.49-0.52 \mathrm{M} \mathrm{NaCl}(27-32 \mathrm{~min})$ in a gradient profile (----) at a flow rate of $1 \mathrm{ml} / \mathrm{min}$. Eluate indicated with bar was collected. (B) The fraction obtained in (A) was further purified by the same column. OLL was eluted with $0.47-0.50 \mathrm{M} \mathrm{NaCl}(19-21 \mathrm{~min})$.

tested in a similar system as described above.

\section{Analytical Methods}

SDS-PAGE were performed according to the method of Laemmli (12) using 12.5\% separation gel with standard protein markers. Protein bands were stained with Coomassie Brilliant Blue R-250 solution. Protein concentration was determined according to the method of Lowry et al. (16), using bovine serum albumin as a standard.

Amino acid composition was analyzed with a Hitachi model L-8500 amino acid analyzer. Sample was hydrolyzed in $6 \mathrm{~N} \mathrm{HCl}$ containing $1 \%$ phenol or under $\mathrm{N}_{2}$ gas at $110^{\circ} \mathrm{C}$ for $24 \mathrm{~h}$.

Sugar composition was determined by the method of Lehnhardt and Winzler (13) using a Finnigan TSQ-700 GC-MS apparatus.

$\mathrm{N}$-Terminal amino acid sequence analysis was carried out by automated Edman degradation in an Applied Biosystems 477A gas-phase sequencer. Secondary structure of the N-terminal sequence was predicted by the method of Chou and Fasman (3).

\section{RESULTS AND DISCUSSION}

In recent studies, we have purified and characterized the rhamnose-binding lectins from roe of Silurus asotus (8) and Osmerus eperlanus mordax (unpublished data). The molecular masses of SAL, OML-1, $-2,-3$ and -4 are $33 \mathrm{KDa}, 32 \mathrm{KDa}, 25 \mathrm{KDa}$, $26 \mathrm{KDa}$ and $26 \mathrm{KDa}$, respectively. These all lectins strongly agglutinated rabbit erythrocytes and this agglutination was inhibited by L-rhamnose and other related saccharides. However, OML-4 agglutinates human ABO-type erythrocytes in contrast with SAL and OML-1 3 that possessed anti-B-like hemagglutination activity.

In our experiment, the sequential chromatographies of anion-exchange, affinity and cationexchange were suitable method for the purification of fish roe lectins. Generally, when saline-extracted fractions (SEFs) from fish roe were applied to the DE23 anion exchange column, the lectin activity was eluted with $10 \mathrm{mM}$ PB. Then rhamnose-binding lectins were adsorbed to the galactose-Sepharose resin. The yield of sugar-binding proteins obtained by using galactose- and rhamnose-Sepha- 


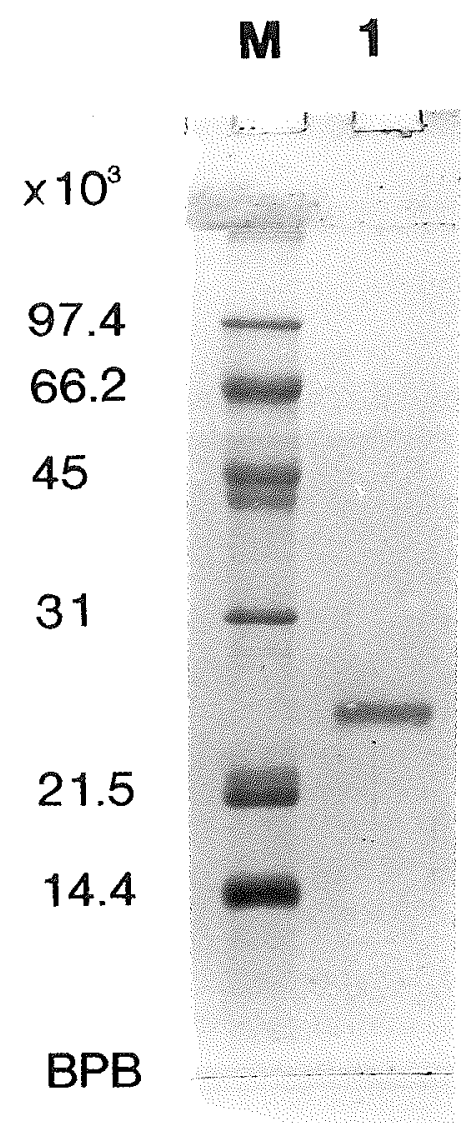

Fig. 3 SDS-PAGE pattern of OLL. Lane 1, OLL, Lane $\mathrm{M}$, marker proteins. Marker proteins used were: phosphorylase $b(97,400)$, bovine serum albumin $(66,200)$, ovalbumin $(45,000)$, carbonic anhydrase $(31,000)$, soybean trypsin inhibitor $(21,500)$ and lysozyme $(14,400)$. BPB, Bromophenol Blue

rose column were the same (data not shown). Further purification could be done by HPLC on the column of TSK gel CM-5PW. This procedure was applied to the purification of OLL. As shown in Fig. 1, two peaks were observed in adsorbed fraction on the affinity column. Since the hemagglutination activity of the second peak fraction (GSA-2) was higher than the first peak fraction, we have further purified GSA-2. Fig. 2 shows elution profiles of GSA-2 on TSK gel CM-5PW. The last peak eluted with $0.49-0.52 \mathrm{M} \mathrm{NaCl}$ was collected (Fig. 2A) and then rechromatographed on the same column with different gradient profile indicated in Fig. 2B. OLL was eluted with $0.47-0.50 \mathrm{M} \mathrm{NaCl}$ and a 95fold purification was achieved when OLL was compared with SEF because HUs of SEF and OLL were 27 and 2,560, respectively. On SDS-PAGE, OLL migrated as a single band with a molecular weight of $26 \mathrm{KDa}$ under reducing condition (Fig. 3). This molecular weight of OLL is the same to those of OML-3 and -4. Kubo and Kawasaki (11) reported a 26-KDa $\mathrm{Ca}^{2+}$-dependent rhamnose-binding lectin, which participates in a construction of epithelial tissue from body fluid of American cockroach (Periplaneta americana). Although both OLL and $P$. americana lectin were $26-\mathrm{KDa}$ rhamnose-binding protein, OLL did not require $\mathrm{Ca}^{2+}$ for its lectin activity (data not shown).

OLL agglutinated rabbit and human A, B and Otype erythrocytes and sarcoma-180 murine ascites tumor cells at the minimum concentration of 0.39 , $400,25,400$ and $15 \mu \mathrm{g} / \mathrm{ml}$, respectively, for obvious agglutination (data not shown). Table 1 shows the sugar-binding specificity of OLL. L-Rhamnose and L-rhamnose-containing disaccharides, neohesperidose and rutinose, strongly inhibited the OLLinduced hemagglutination. Since L-rhamnose, Lmannose, L-lyxose, D-galactose and D-fucose were potent inhibitors, and since the inhibitory activities of melibiose, raffinose and stachyose were significantly higher than those of lactose and lactulose (Table 1), OLL is thought to recognize hydroxyl orientations at $\mathrm{C} 2$ and $\mathrm{C} 4$ positions of the pyranose ring and $\alpha$-galactosyl structures. Since L-rhamnose is not a naturally occurring sugar in vertebrates, the physiological significance of the rhamnosebinding lectins is still unclear. However, Ozaki et al. (19) reported that amago lectin may participate in host defense mechanisms and, in human immune system, Grillon et al. suggested that the rhamnosebinding lectin may have relevance to the antibacterial effect against microorganisms which have $\alpha$ L-rhamnosyl residue in their surface glycoconjugates (7).

Table 2 shows amino acid compositions of OLL and OML-4. These two lectins contained high amounts of Asp plus Asn, Thr and Ser, and similar amounts of other amino acids except for Cys, His and Arg. As shown in Fig. 4, the N-terminal sequences of OLL and OML-2 4 were similar and YGR (-Tyr-Gly-Arg-) sequence at the position of 27-29 was conserved in these six lectins. Sugar contents of OLL and OML-4 were both less than 1\% $(\mathrm{w} / \mathrm{w})$. Glucose, mannose and galactose were detected (Table 3), and the trace amounts of other sugars such as fucose, glucosamine and galactosamine were also detected (data not shown). Since the similar sugar compositions have been observed in the roe lectins of Misgurnus anguillicaudatus (22) and Plecoglossus altivelis (21), this sugar composi- 
Table 1 Inhibition of Hemagglutination Activity of OLL by Saccharides $^{\mathrm{a}}$

\begin{tabular}{lc}
\hline \multicolumn{1}{c}{ Saccharide } & Concentration $(\mathrm{mM})^{\mathrm{b}}$ \\
\hline L-Rhamnose & 0.004 \\
D-Galactose & 0.75 \\
L-Galactose & 200 \\
Methyl- $\alpha$-D-galactoside & 0.094 \\
Methyl- $\beta$-D-galactoside & 0.188 \\
$N$-Acetyl-D-galactosamine & $>200$ \\
D-Mannose & $>200$ \\
L-Mannose & 0.03 \\
D-Fucose & 0.75 \\
L-Fucose & 25 \\
D-Xylose & 50 \\
L-Xylose & 100 \\
D-Lyxose & 25 \\
L-Lyxose & 0.188 \\
Neohesperidose & 0.002 \\
Rutinose & 0.002 \\
Lactose & 12.5 \\
Lactulose & 12.5 \\
Melibiose & 0.094 \\
Raffinose & 0.094 \\
Stachyose & 0.094 \\
\hline
\end{tabular}

${ }^{a}$ In the presence of $2 \%$ rabbit erythrocyte suspension and $8 \mathrm{HU}$ of OLL in $50 \mu \mathrm{l}$. ${ }^{\mathrm{b}}$ Minimum concentration of saccharides required for complete inhibition

tion may be typical in the fish roe rhamnose-binding lectins.

Therefore, it was suggested that OLL and OML4 , derived from different species of fish roe, are similar in respect to (i) molecular weight, (ii) cell agglutination profile, (iii) sugar specificity, (iv) amino acid and sugar composition, and (v) N-terminal sequence. Moreover the predicted secondary structure suggested that OLL and OML-1 4 may have typical $\beta$-turn repeats in the $\mathrm{N}$-terminal region (Fig. 4). Since the relationship between secondary structure and biofunctional role(s) of these lectins is still unknown, the determination of complete amino acid sequences is necessary, and it is interesting to examine whether or not some consensus amino acid sequences are conserved in rhamnose-binding lectin molecules.

This study was supported by a Science Research Promotion Fund from the Japan Private School Promotion Foundation.

Received 8 October 1992; and accepted 26 October 1992

\section{REFERENCES}

1. Bevilacqua M. P., Stengelin S., Gimbrone M. A. and SeED B. (1989) Endothelial leukocyte adhesion molecule 1: An inducible receptor for neutrophils related to complement regulatory proteins and lectins. Science 243, 11601165

2. Camerini D., James S. P., Stamenkovic I. and Seed B. (1989) Leu-8/TQ1 is the human equivalent of the Mel-14 lymph node homing receptor. Nature 342, 78-82

3. Chou P. Y. and Fasman G. D. (1979) Prediction of $\beta$-turns. Biophys. J. 26, 367-383

4. Etzler M. E. and Kabat E. A. (1970) Purification and characterization of a lectin (plant hemagglutinin) with blood group A specificity from Dolichos biflorus. Biochemistry 9, 869-877

5. Filipovich A. H., Vallera D. A., Youle R. J., HaAke R., Blazar B. R., Arthur D., Neville D. M., Ramsay N. K. C., McGlave P. and Kersey J. H. (1987) Graft-versus-host disease prevention in allogeneic bone marrow transplantation from histocompatible siblings. Transplantation 44, 6269

6. Goldstein I. J., Hughes R. C., Monsigny M., Osawa T. and Sharon N. (1980) What should be called a lectin? Nature 285, 66

7. Grillon C., Monsigny M. and Kieda C. (1990) Cell surface lectins of human granulocytes: their expression is modulated by mononuclear cells and granulocyte/macro- 
Table 2 Amino Acid Compositions of OLL and OML-4

\begin{tabular}{|c|c|c|}
\hline \multirow{2}{*}{ Amino acid } & \multicolumn{2}{|c|}{ Residues in 100 residues } \\
\hline & OLL & OML-4 \\
\hline Asx & 13.7 & 11.9 \\
\hline Thr ${ }^{\mathrm{a}}$ & 11.7 & 11.7 \\
\hline $\mathrm{Ser}^{\mathrm{a}}$ & 10.7 & 12.0 \\
\hline Glx & 4.8 & 5.5 \\
\hline Gly & 8.0 & 9.4 \\
\hline Ala & 5.0 & 5.4 \\
\hline Cys $^{b}$ & 2.7 & 1.0 \\
\hline $\mathrm{Val}^{\mathrm{c}}$ & 7.4 & 8.6 \\
\hline Met & 1.1 & 1.4 \\
\hline $\mathrm{Ile}^{\mathrm{c}}$ & 5.6 & 6.6 \\
\hline Leu & 6.8 & 5.6 \\
\hline Tyr & 4.8 & 6.3 \\
\hline Phe & 2.3 & 2.3 \\
\hline $\operatorname{Trp}^{d}$ & $\mathrm{ND}^{\mathrm{e}}$ & $\mathrm{ND}$ \\
\hline Lys & 2.2 & 2.2 \\
\hline His & 3.0 & 0.9 \\
\hline Arg & 5.5 & 3.3 \\
\hline Pro & 4.5 & 5.9 \\
\hline
\end{tabular}

${ }^{a}$ Corrected to zero hydrolysis time values based on the 24,48 and $72 \mathrm{~h}$ hydrolysis value. betermined as cysteic acid after performic acid oxidation. ${ }^{\mathrm{c}} 72 \mathrm{~h}$ hydrolysis value. ${ }^{\mathrm{d}} \mathrm{Hydrolyze}$ in $4 \mathrm{~N}$ methane sulfonic acid containing $2 \%$ tryptamine hydrochloride for $24 \mathrm{~h} .{ }^{e} \mathrm{ND}$, not detected

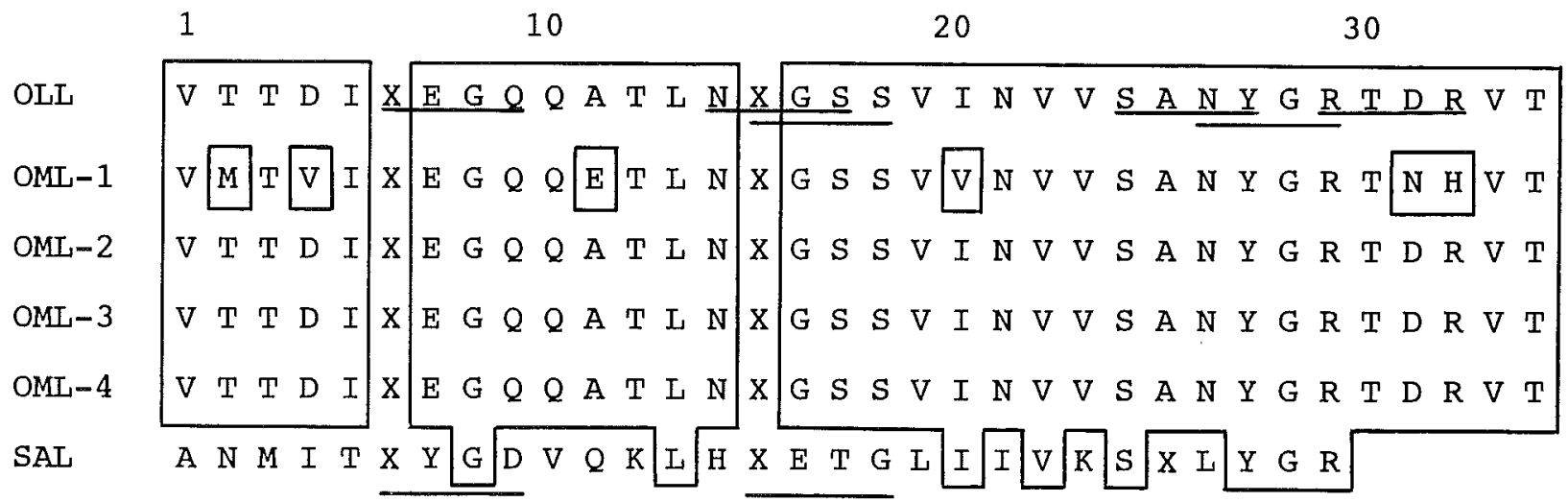

Fig. 4 Comparison of N-terminal amino acid sequences between OLL, OML-1 4 and SAL (see text). Identical residues are enclosed in boxes. Predicted $\beta$-turn structure regions were indicated with underlines. $\mathrm{X}$ represents undefined residue. 
Table 3 Sugar Compositions of OLL and OML-4

\begin{tabular}{lcc}
\hline \multirow{1}{*}{ Sugar } & \multicolumn{2}{c}{ Content $(w / w \%)$} \\
\hline Mannose & OLL & OML-4 \\
Glucose & 0.12 & 0.26 \\
Galactose & 0.35 & 0.48 \\
\hline
\end{tabular}

phage colony-stimulating factor. Glycobiology 1, 33-38

8. Hosono M., Kawauchi H., NitTa K., Takayanagi Y., Shiokawa H., Mineki R. and Murayama K. (1993) Purification and characterization of Silurus asotus (Catfish) roe lectin. Biol. Pharm. Bull. 16 (in press)

9. Johnston G. I., Cook R. G. and McEver R. P. (1989) Cloning of GMP-140, a granule membrane protein of platelets and endothelium: Sequence similarity to proteins involved in cell adhesion and inflammation. Cell 56, 1033-1044

10. Krajhanzl A. (1990) Egg lectins of invertebrates and lower vertebrates: Properties and biological function. $A d v$. Lectin Res. 3, 83-131

11. Kubo T. and KawaSAKi K. (1992) Role of humoral lectin family in the leg regeneration of American cockroach. Tanpakushitsu Kakusan Koso 37, 810-819 (in Japanese)

12. LAEMMLI U. K. (1970) Cleavage of structural proteins during the assembly of the head of bacteriophage T4. Nature 227, 680-685

13. LEHNHARDT W. F. and W INZLER R. J. (1968) Determination of neutral sugars in glycoproteins by gas-liquid chromatography. J. Chromatogr. 34, 471-479

14. Levene C., Sela R., Blat J., Friedlaender M. and Manny N. (1986) Intracellular hemolysis and renal failure in a patient with $\mathrm{T}$ polyagglutination. Transfusion 26, 243-245
15. Lotan R. and Sharon N. (1978) Peanut (Arachis hypogaea) agglutinin. Meth. Enzymol. 50, 361-367

16. Lowry O. H., Rosebrough N. J., Farr A. L. and Randall R. J. (1951) Protein measurement with the folin phenol reagent. J. Biol. Chem. 193, 265-275

17. Nitta K., TaKayanagi G. and Kawauchi H. (1984) Reactivity of lectin from Xenopus laevis eggs towards tumor cells and human erythrocytes. Chem. Pharm. Bull. 32, 23252332

18. NitTa K., TAKaYANaGi G., KaWAUChI H. and HaKomori S. (1987) Isolation and characterization of Rana catesbeiana lectin and demonstration of the lectin-binding glycoprotein of rodent and human tumor cell membranes. Cancer Res. 47, 4877-4883

19. Ozaki H., OhwaKi M. and Fukada T. (1983) Studies on lectins of amago (Oncorhyncus rhodurus) I. Amago ova lectin and its receptor on homologous macrophages. Dev. Comp. Immunol. 7, 77-87

20. Prigent M. J. and Bourrillon R. (1976) Purification and characterization of a lectin (plant hemagglutinin) with $\mathrm{N}$ blood group specificity from Vicia graminea seeds. Biochim. Biopliys. Acta 420, 112-121

21. SaKakibara F., Kawauchi H. and Takayanagi G. (1985) Blood group B-specific lectin of Plecoglossus altivelis (Ayu fish) eggs. Biochim. Biophys. Acta 841, 103-111

22. SaKakibara F., Takayanagi G. and Kawauchl H. (1981) A L-rhamnose-binding lectin in the eggs of Misgurnus anguillicaudatus. Yakugaku Zasshi 101, 918-925 (in Japanese with English abstract)

23. Sharon N. and Lis H. (1989) Lectins, Chapman and Hall, London, 1-107

24. Yuan M., Itzkowitz S. H., Boland C. R., Kim Y. D., Tomita J. T., Palekar A., Bennington J. L., Trump B. F. and KIM Y. S. (1986) Comparison of T-antigen expression in normal, premalignant, and malignant human colonic tissue using lectin and antibody immunohistochemistry. Cancer Res. 46, 4841-4847 